\title{
A Cultural Approach to the Southern Mediterranean Crisis
}

\section{Laure Borgomano-Loup *}

Relatively little attention has been paid to the study of the cultural roots of security concepts. This is because security is seen as the exclusive preserve of geopolitics or geo-strategy, both of which tend to focus more on international relations or military capabilities than on cultural anthropology. Nevertheless, the historical and cultural conditions under which crises start and develop are of the utmost importance, because they shape the way we understand these conflicts and ultimately find solutions to them. This is particularly true of the southern Mediterranean, a region where security-related crises are recurrent and where parties on either side of the Mediterranean Sea have a different understanding of the main security threats.

Instead of discussing the relative value of these divergent perceptions, the NATO Defense College recently organized a Workshop dedicated to Cross-Cultural Perceptions of Security Issues in the Mediterranean. ${ }^{1}$ We decided to approach security issues from a new angle. Leaving aside military considerations and current political conditions, we focused on the anthropological roots underlying our perceptions of security. Our conviction was that the common history of disputes and economic and population exchange linking both sides of the Mediterranean has caused parties to these conflicts both to grow closer to as well as to become estranged from each other. The result is that we interpret current security issues on the basis of a sort of mirror-image interpretation of history - a reversed picture of the same event. This essay will address the main findings of this Workshop and discuss how they can help us to invent new ways of solving security issues in the Mediterranean.

In this endeavor, the working group drew extensively on the works and theories developed by Algerian author Mohammed Arkoun and by Georges Corm, a world-renowned academic and former Minister of Finance in Lebanon. Mohamed Arkoun developed the theory of mytho-history and mytho-ideology. According to this theory, real historical facts are transfigured and interpreted as foundation myths, converted into idealized representations that end up imposing their meaning upon the past, as well as interpreting the present and charting the future. Once these intellectual structures become entrenched as mytho-ideologies, they defy all critical historical analysis. That leads to the difficulties confronted by parties on either side of the Mediterranean in sharing common views on security issues. ${ }^{2}$ These anthropological concepts are highly valuable for understanding how historical realities such as the Arab invasions, the de-

* Dr. Laure Borgomano-Loup is Research Advisor at the NATO Defense College in Rome.

1 First Mediterranean Dialogue Workshop, Rome, 7-8 July 2003. The Programme, Introduction and Report are available on the NDC's Website, available at http://ndc.nato.int. Click on Research Branch, Publications, more on Seminar Report series.

2 See Mohammed Arkoun and Joseph Maïla, De Manhattan à Bagdad-Au-delà du Bien et du Mal (Paris: Desclée de Brouwer, 2003). 
velopment of Islamic religion, and Western colonization shape our contradictory interpretations of current migration issues.

In the case of Georges Corm, he has devoted the major part of his writing to the Middle East crisis and to the history of the Arab world. ${ }^{3}$ In one of his most recent works, Orient-Occident, la fracture imaginaire, he stresses that there is absolutely no trace of any historical animosity between the West and the South that could create a clash of cultures or civilizations. In fact, this "imaginary fault line" helps to conceal the real and powerful national economic and political interests on both sides of the Mediterranean Sea. Only a thorough and precise historical analysis can help us to understand how these "clichés" about the West and the South shape our current understanding of terrorism and violence.

Due to the limits of our Workshop, the group confined their thinking to two topics: first, the links between invasion, colonization, and immigration; and, second, the links between religion, politics, and violence.

\section{Invasion and Immigration}

Traces of the memory of the Ottoman invasions and the Arab occupation of part of Southern Europe can be detected in Northern European countries' perceptions of immigration. No matter how reassuring the statistics may be, and notwithstanding the fact that migration affects first and foremost the Southern Mediterranean countries, Europeans in general portray these immigrants as dangerous and reminiscent of the Saracen hordes that used to raid Europe. The rational fear of being unable to assimilate new populations is replaced by the suspicion that these Southern hordes are intent on harming Europe. This, then, heightens anti-Arab and anti-Muslim feelings, which are in turn compounded by international crises, the expansion of radical Islam, and the fear of terrorism. This takes us right back to square one: the Southern immigrants are perceived as being impossible to assimilate, dangerous, and hostile. This is followed by radical extreme-right appeals to the memory of "mythical" ancestors, such as "Charles Martel who stopped the Arabs at Poitiers." Fear of the Muslim world has, therefore, taken the place that the fear of Communism used to fill in the $1950 \mathrm{~s},{ }^{4}$ with creeping and hostile invasions providing the myth underpinning fears of immigration.

The "Southern," largely Muslim countries are no better. Their opposition to globalization and their criticism of the West's cultural and economic hegemony reflect the fear that their cultural and religious identity will be swept away by the mass dissemination of Northern concepts. The narrative of the "Southern immigrants' invasion" of the North is mirrored by the "invasion of Northern values" in the South. To some ex-

3 See, in particular, Georges Corm, Le Proche Orient Eclaté - 1956/2003 (Paris: Folio, 2003); Orient-Occident, la fracture imaginaire (Paris: Editions La découverte, 2002); and Méditerranée, espace de conflit, espace de rêve (Paris: L'Harmattan 2001).

4 The most successful popular example of this product of imagination is the film "Them!", made by Gordon Douglas in 1954. In this film, an American town is attacked by giant ants living underneath the town and organized very much along the lines of Communist society. 
tent, current anti-Western Islamist thinking resembles the thinking of national liberation movements and Arab nationalist ideology of the 1950s and the 1960s. At that time, colonization, and the attendant political, social, and cultural institutions it imposed upon colonized peoples, eventually came to embody the historical and theoretical justification for rejecting this cultural invasion. But in current discourse, all colonization does is revive memories of the Crusades. And it is memories of the Ottoman and Arab-Berber invasions, the Crusades and colonization, that are now blocking any kind of rational thinking about intercultural exchange and the cross-fertilization of values and institutions.

\section{Religion, Politics, and Violence}

The current Western focus on Islam as the main explanation for the recurrent crises in the South provokes uneasiness and frustration in the Muslim and Arab world. Some Western commentators claim that there could be some kind of historical incompatibility between Islam and democracy, Islam and modernity, and Islam and secularism. In actual fact, all these concepts have to be closely analyzed if we want to avoid the most racist and harmful clichés.

Let us first address the link between secularization and the modern state. Following the Age of Enlightenment, modern states were set up in Western Europe in which religion was separated from politics. Nevertheless, this separation varied in form from country to country, according to each country's history. France, which for some considerable time had been regarded as the "Roman Catholic Church's eldest daughter," implemented an even stricter form of separation at the beginning of the twentieth century, since most of the anti-Republican forces at that time were Catholic. However, the Declaration of Human Rights, which is an integral part of the Constitution of the Fifth Republic, still comes under the auspices of the Supreme Being. In England, the Queen is still the head of the Anglican Church. In Germany, the state is religiously neutral, although there is some co-operation between state and churches in selected areas, such as education. In each case, the relationship between the state, society, and religion (or the dominant religions) takes a special institutional form that bears no direct relation to the prevailing degree of religious fervor in that particular country. In both Europe and the United States, religious values continue to play a political and social role and contribute to contemporary life. However, religion does not impose its law upon the politicians. We should, therefore, draw a distinction between secularization-the objective 'deconsecration' of political and social activity - and laicization, which is a more subjective and ideological phenomenon that leads to the questioning of religious values. ${ }^{5}$

The concept of laicity does not have any meaning in the Maghreb and the Mashrek countries, which is not to say that followers of Islam are necessarily against modernity. In fact, as Burham Galioun underlines, Islam has provided the Arab and Muslim coun-

5 See, in particular, Burham Galioun, Le malaise arabe, l'Etat contre la nation (Paris: L'Harmattan, 1991), and Islam et politique, la modernité trahie (Paris: Editions la Découverte, 1997). 
tries with a national or community identity in times of aggression or colonization, with a primary source for legitimizing contemporary social change ${ }^{6}$ and, most recently, with a vehicle that enabled the Arab and Muslim masses, who have been rejected or marginalized by their own governments, to express their demands and frustrations.

As far as violence is concerned, once again, there is no automatic link between one specific religion and violence. Consequently, it is somewhat pointless to try and establish whether the Koran preaches violence and Christianity preaches love or vice versa. As Olivier Roy observes, it is not so much what the Koran says that counts as what Muslims say about the Koran. ${ }^{7}$ Different readings of the Gospel at the same historical moment in Europe produced the merciful gentleness of St. Francis of Assisi on the one hand, and the inquisitorial violence of St. Dominique on the other. Violence, in its sacrificial form, is part of many religions, although it often takes on a cathartic role within them. In the case of providing a justification for war, this is a matter for politics. French historian Jean Flori has shown how it took Christianity, which in its essence rejects violence and war, eleven centuries to carry out a drastic doctrinal reform that enabled it to justify the holy war of the Crusades and to sanctify the ideal of the 'soldier monk.' Defensive war started out as a necessity in order to protect the empire when it became Christian. Subsequently, the Papacy's ever-growing involvement in temporal affairs gradually led to the idea that war could be justified, that it could be just and, finally, that it could be holy if there was a need to defend the Holy Land. By the end of the eleventh century, Christianity had, therefore, reached the same conclusions about the sacred right to war that would soon be embodied in the Muslim notion of jihad. ${ }^{8}$ Subsequently, the so-called wars of religion were to pit Christians against each other, to the great chagrin of Erasmus. ${ }^{9}$ Now that the Catholic Church no longer wields temporal power, the message it preaches is a resolutely peaceful one. ${ }^{10}$

When Islamic fundamentalists invoke Islam for political or violent ends, they are exploiting a specific historical source for their own purposes and without any critical interpretation. Their efforts are aided by the collapse of nationalist and socialist ideologies over the last few decades. Consequently, religion is filling the ideological void that has been left by the failure of secular movements that carried millenarian promise. There is, therefore, an urgent need to shed this ahistorical vision of Islam, and this applies both to the West, which is always eager to seek justification for its fears in the Koran, and to the Muslim world, where some Muslims are doing their utmost to prove

${ }^{6}$ For instance, the role played by the Reformist Ulemas and the tradition of Islâh set in motion by Jamal Eddin al-Afghani. See also Maurice Borrmans, Dialogue islamo-chrétien à temps et contretemps (Versailles: Editions Saint-Paul, 2002).

7 See Olivier Roy, L'Islam mondialisé (Paris: Editions du Seuil, 2002).

8 See Jean Flori, Guerre sainte, Jihad, Croisade (Paris: Editions du Seuil, 2002).

9 See Erasmus, The Complaint of Peace. In this text, published in 1517, Erasmus defended the idea that if men make war, notwithstanding their religion, it is basically because they like making war more than anything else. He also puts forward the idea that war between Christians is doubly detestable.

${ }^{10}$ See the Vatican's attitude towards the most recent intervention in Iraq. 
the theological futility of Bin Laden's extremist theories. ${ }^{11}$ We need to give serious thought to the anthropological and political aspects of religion, rather than focusing exclusively on religious scriptures. ${ }^{12}$ In fact, violence is part and parcel of any millenarian movement that offers its followers salvation on earth and/or in heaven. In this sense, Georges Corm echoes Mohamed Arkoun when he condemns the continuing influence of eschatological religion in what appear to be the most secular of modern Western theories. Salvation is not the exclusive preserve of the revealed religions. It has been, and it still is, a powerful ideological and moral driving force behind the United States' vision of itself and its mission in the world. ${ }^{13}$ It shaped the Western eschatological vision of the end of history through science in the nineteenth century and through the triumph of democracy and economic liberalism today. ${ }^{14}$

\section{What Role Does a Cultural Approach Play in Conflict Resolution?}

All workshop participants underlined the importance of considering historical and cultural factors in both the development and the assessment of crises. Thus, developing a sound critical historical analysis is a necessary prerequisite for demolishing entrenched positions imbued with mytho-history and mytho-ideology. This is particularly crucial in the Southern countries, where the objective discussion of history is often viewed with suspicion by authoritarian regimes. In order to promote increased consideration of these issues, we could try various approaches on either side of the Mediterranean Sea. One way might be to launch a program for writing a common or a comparative history, focusing on events that are of importance to both parties, such as the Crusades. But academic knowledge is not enough. We might also take stock of the way the Germans and the French have managed to overcome their long history of conflict by developing educational and cultural programs. For instance, governments might organize seminars and events around the concept of Mediterranean Sites of Memory or Lieux de Mémoire Méditerranéens. This concept was developed some years ago by French historian Pierre Nora. As the NATO Defense College is a politico-military institution, it could devote an event to the common strategic and military memories of nations on both sides of the Mediterranean: flags, national anthems, famous military leaders and heroes, cemeteries, monuments to the dead, etc. The idea would be to bridge the gap between antagonistic histories by highlighting their factual as well as their imaginary aspects. In any case, all participants in the workshop underscored the

${ }^{11}$ See Maha Azzam, "Al Quaeda, the Misunderstood Wahhabi Connection and the Ideology of Violence," RIIA, Middle-East Programme, Briefing Paper 1 (London, 2003).

12 That does not, of course, diminish the importance of the role it plays in the dialogue between religions, which is always useful for bringing people closer together.

${ }^{13}$ This is the theory of American exceptionalism as embodied in two models: the safeguarding of the free and republican Promised Land, and the crusade for civilization and democracy. For an analysis of these theories, see Pierre Hassner and Justin Vaïsse, Washington et le mondeDilemmes d'une superpuissance (Paris: Editions Autrement, 2003).

14 See Corm, Orient. 
need for the West to have a better understanding and knowledge of Southern Mediterranean culture and history before becoming involved in the region, both politically and militarily. They also suggested that military leaders and diplomats should take better advantage of the findings of regional analysts as well as the resources of the various churches and commercial enterprises active in the region.

The participants also suggested that both parties could develop more creative and long-term modes of thinking about Mediterranean security. During the workshop, attendees watched a video on the image of Arabs in the media that had been made specifically for this workshop by the Centro Archivio Immigrazione in Rome. The objective was to highlight the various negative clichés that continue to prevent us from having a clear understanding of Mediterranean security issues. Participants suggested that the Arab world and Israel prepare a similar video on the image of the West as seen through their eyes. The workshop also featured a simulation exercise on the Mediterranean countries' integration into NATO under specific conditions. The objective was to analyze how our various and specific historical and cultural perceptions might impact policies that would influence such an integration. Such exercises are powerful instruments for uncovering the underlying perceptions that prevent us from accurately anticipating what the backlash of a particular intervention might be. It might also be interesting to run similar simulation exercises on topics such as developing a strategic concept for the Mediterranean Dialogue countries, developing regional co-operation in the Maghreb and the Mashrek, or inviting more Mediterranean countries to join the Mediterranean Dialogue.

\section{Conclusion}

Inputs from the humanities and social sciences, such as history, anthropology, and sociology, are all too often absent from the processes of formulating our military and diplomatic policies. But there can be no viable model of conflict prevention in the southern Mediterranean unless we have a better understanding of its history, society, and culture. Trust, not power, is the key to avoiding conflicts or helping to solve crises. Indeed, diplomatic agreements or military alliances are of little use to maintaining a sustainable peace if the parties concerned are not deeply convinced of the benefits of a peaceful solution. 


\section{Bibliography}

Arkoun, Mohammed, and Joseph Maïla. De Manhattan à Bagdad-Au-delà du Bien et du Mal. Paris: Desclée de Brouwer, 2003.

Borrmans, Maurice. Dialogue islamo-chrétien à temps et contretemps. Versailles: Editions Saint-Paul, 2002.

Galioun, Burham. Le malaise arabe, l'Etat contre la nation . Paris: L'Harmattan, 1991. 